\title{
Art and Activism at Museums in a Post-digital World
}

\author{
Tula Giannini \\ Professor of Information \\ School of Information \\ Pratt Institute \\ New York, USA \\ https://sites.google.com/view/tgiannini/ \\ giannini@pratt.edu
}

\author{
Jonathan P. Bowen \\ Emeritus Professor of Computing \\ School of Engineering \\ London South Bank University \\ London, UK \\ http://www.jpbowen.com \\ jonathan.bowen@/sbu.ac.uk
}

\begin{abstract}
Once quiet places protected by walls, museums are increasingly besieged by activist groups. Spurred by social and political causes, they storm the gates bypassing the gatekeepers, to deliver their message and insist that museums become relevant, participatory and interactive, and give voice to their communities and audience. With no place to hide in a sea of digital connections, museums are challenged to find new directions and strategies for the post-digital world. This paper traces these trends, illustrating them using recent examples of art and activism at museums in New York and London, and explores strategies for museums to collaborate with their community and find common ground.
\end{abstract}

Digital activism. Digital art. Digital culture. Digital heritage. Exhibitions. Museums. Post-digital world. Protest.

\section{INTRODUCTION}

Key social movements coalesce around MeToo, decolonize, repatriation, reparation, historical narratives, cultural appropriation, LGBT, and women's rights notwithstanding questions about the ownership of heritage - who's stuff is it? From the perspective of art and the artist, we see an increasing prevalence of blending art with politics and social justice into works of art that deliver political punch and readable messages to their audience. What has made these movements more powerful than ever, is the digital ecosystem to which we are all connected. Our global network where people are communicating sans cesse, brings awareness to causes and crises, while setting the stage for things to go viral at any moment.

This inescapable connectedness of life on the Internet, pumping out an ever-increasing volume of messages and text, from social media via Instagram, Twitter and Facebook, to blogs, publications, news, email, texts, voice, audio, and video, has now become home to social and political movements, and to activists and their causes. Living on a digital platform, local becomes national and global, and digital images, artworks and social movements are juxtaposed in new ways provoking new meanings, so that art occupying an impeachable place in the cannon, might be assailed for being sexist or racist, and the museums showing these works, might be met with demands that they be removed. Artists too can be under attack for sexual abuse, or crossing cultural boundaries of identity and gender, as if political correctness has impinged on the art world.

The reality of post-digital life (Bowen \& Giannini 2014) means that we no longer choose between real and virtual, physical and digital, as we live in a world where everyone is connected on the Internet, a place where past becomes present and intones the future. As our awareness brims with information across time and space, everything can seem like it only happened yesterday; cf. The Beatles in 1965:

\footnotetext{
Yesterday

All my troubles seemed so far away

Now it looks as though they're here to stay

Oh, I believe in yesterday.
}

With the march of time, historical narratives can become set in stone limiting discussion and analysis as they enter the canon of the art history establishment of sorts, as if time had stopped. By the end of the $20^{\text {th }}$ century, following the rise of pop culture and television, and with the advent of the web, the nature of communication radically changed to digital while opening wide the Internet gates to global conversation and the rapid 
expansion of a global digital ecosystem, a home away from home. Art history now moved to a global stage of world culture, which in a real sense has been breaking up history into digital bits that are becoming the raw material for new narratives that challenge the way we think about and interpret the past, with the goal of bringing relevance and contemporary views as we seek inclusion and diversity.

By the dawn of the $21^{\text {st }}$ century, the average person was spending 7 to 8 hours per day looking at a TV screen, and within a few years that number rose by another 5 hours per day spent on computer and smartphone screens, so that by 2018 most Americans were spending 10-12 hours of screen time per day (Fottrell 2018). Concurrently, the art world experienced a steady increase in the use of screens as a media for art. Beginning in the 1980s, video was being used by major artists as Andy Warhol and the Japanese artist Nam June Paik. In the 2000s, with the proliferation of digital media screens, akin to a new digital art palette of artistic expression, the rise of digital art accelerated reaching millions of Internet viewers. At the same time, we have been witnessing a mass migration to the digital ecosphere of social and cultural movements accelerated by social media occupying the web's town square and converging to form a new phenomenon often referred to as the postdigital world, where we look at screens and through a digital lens to see ourselves and the world in real and virtual life.

\section{Looking at a Screen (by T. Giannini)}

Looking at a screen
Silent and unseen
want to scream
Can't move
I'm mesmerized
My mind paralyzed
My life
Unrealized
Change the channel
No controller
Feels bipolar
Activism
Passivism
Prisms of the mind
I close my eyes
I see your face
Fading into the past
My cell phone rings
My heart beats fast
Wrong number
How long can this last
Drifting into slumber
Look away from the screen
Dream, dream, dream

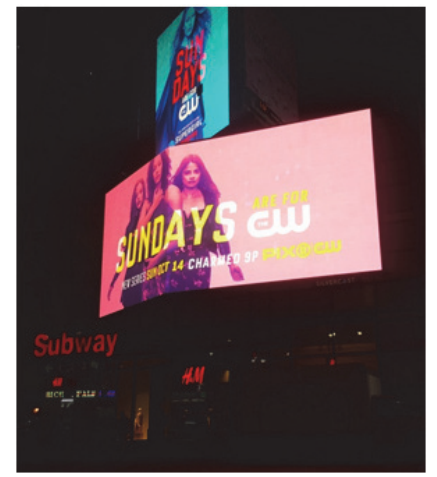

Figure 1: Large digital media screens on $7^{\text {th }}$ Avenue, across from Penn Station in New York City, advertising two Sunday evening PIX@CW TV shows, Supergirl (top) and Charmed, both are about powerful politically savvy women. The screen images change every few seconds. Photograph by T. Giannini.

TV screens are the building blocks for the works of video artist Nam June Paik. His 1989 work, Fin de Siècle II is composed of some 200 TV sets was on display at the Whitney Museum's exhibition Programmed: Rules, Codes, and Choreographies in Art, 1965-2018, and makes a powerful statement about pop culture and avant-garde art as with Charlotte Moorman's TV cello by Paik (Wolkoff 2019) that resonates today, as Paik places the screen front and centre, delivering messages on gender, hearing pop icon David Bowie screaming "bored". TV sets are again the building blocks of his 1996 work, Electronic Superhighway, Continental U.S., a TV set sculpture with a TV set for each of the 50 states in the form of a map of the USA (see Figure 2). The TVs are connected by a series of wires, their colourful flashing images forming shapes and patterns that seem to overcome the work's physicality, reminiscent of Adrian Piper's work constructed of 36 TV sets, that was on view in her solo exhibition at MoMA in 2018 (see Figure 3).

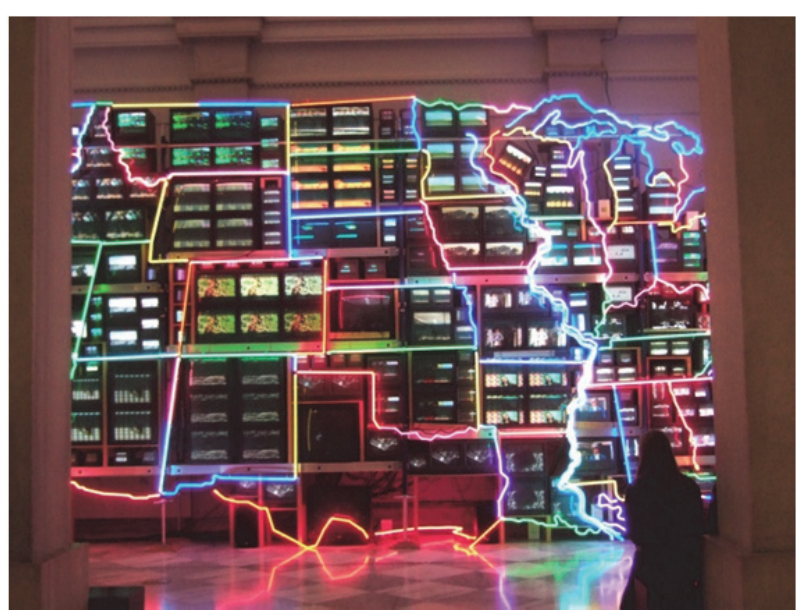

Figure 2: Electronic Superhighway, Continental U.S., Alaska, Hawaii, by Nam June Paik, 1995-1996.

American Art Museum, Smithsonian, Washington D.C. Photograph by Libjbr (2011). Wikimedia Commons. http://commons. wikimedia.org/wiki/File:Electronic Super highway by Nam June Paik.jpg 


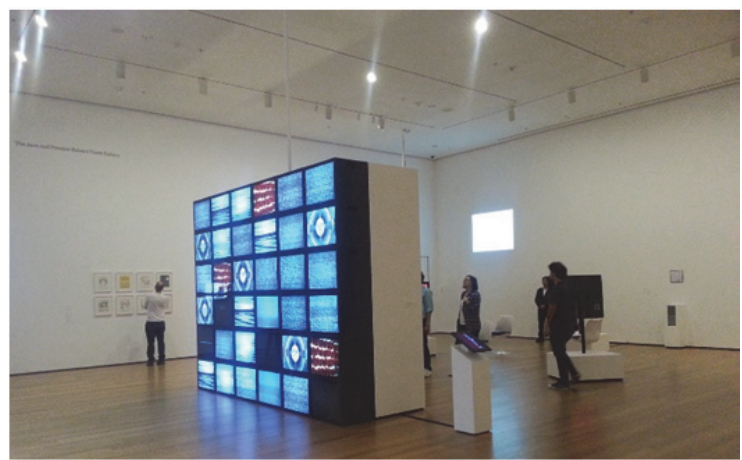

Figure 3: Installation view from the MoMA exhibition, Adrian Piper, A Synthesis of Intuitions, 1965-2016. Piper's large work is built around 36 TV sets, five show CBS channel identification, others blurred electrical interference. Photograph by T. Giannini (May 2018).

\section{DIGITAL CULTURE AND ACTIVISM IN MUSEUMS}

At the heart of the current contextual shift is that people are fully immersed in the global context of digital culture and digital activism (Kaun \& Uldam 2017).These changes are causing artists to rethink their roles in society as they recognize the power of art to change the way they see themselves and the world, while offering new ways for people to understand their relationship to cultural heritage.

Living in a digital culture, everyone is included in the conversation about the why, when and where did we get to this battleground of questions concerning cultural and personal identity and authenticity that dominate political discourse for which museums have moved to centre stage, the public square of cultural debate. Museums remind us of who we are who we were, and how far we have travelled. They tell us what is valuable and valued, revealing the journey of each object from its provenance to its story. And with online database collections, everyone has access to this knowledge from anywhere in the world, and can share, expand and comment on the information and with a click, sending it around the world as it spans out across the digital ecosystem where we all reside. Increasingly, we witness mass takeovers of museums by a plethora of social justice groups in conjunction with major exhibitions.

\section{Activist Trends in Graduate Education}

We see similar trends in graduate programs in art and practice which increasingly are placing emphasis on artists' research in social and political contexts. For example, the St Lucas School of Arts in Antwerp, Belgium is offering an "Advanced Master in Artistic Research in a Social-Political Context ... that focuses on research development of artists and designers whose practice is anchored in a social-political context." The Academy of Fine
Arts Vienna, offers a "PhD-in-Practice" that takes a decidedly "transdisciplinary and international bent" and is built on a concept of arts-based research that relates to critical studies "in the context of feminist, queer, postcolonial, ecological, postMarxist and other political and emancipatory projects" as a space for the negotiation of social, political, cultural and economic conflicts (Akbild 2019).

\section{The Parthenon Marbles and Assyrian Treasures - Questioning the Life of the Object}

The British Museum's 2018 exhibition, Rodin and the Art of Ancient Greece (see Figure 4), sparked renewed calls by the Greek government for repatriation of the Parthenon Marbles (controversially also known as the Elgin Marbles) claiming that they should come home to Greece where they were created, and represent indigenous art and culture (Kaplin 2018).

"One of the most radical artists of the modern era", Rodin found his greatest inspiration in Greek sculpture. Although he never visited Greece, he made numerous visits to the British Museum to experience fist-hand its allure and physical power. "Rodin had already studied the sculptures from books, plaster casts and some originals in the Louvre, the Elgin Marbles at the British Museum influenced his work and thinking about art profoundly. (From wall label, "British Museum a temple of the Muses.")

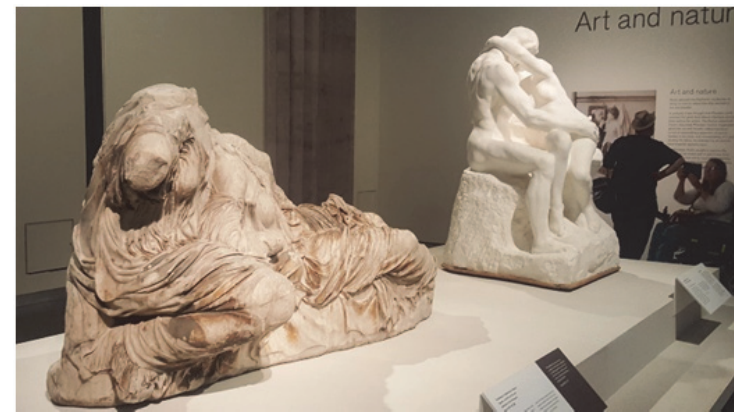

Figure 4: Installation view from the British Museum exhibition, Rodin and the Art of Ancient Greece. To the right is The Kiss, by Rodin. Photograph by T. Giannini (July 2018).

Two clashing perspectives on the status on the Elgin Marbles seem far from resolution (Rea 2019). The Greek government claims they are works stolen by Lord Elgin and need to be returned to Greece, while Hartwig Fischer, Director of the British Museum sees the museum's interaction with the marbles as:
"posing different questions because the objects are placed in a new context. He added: "We should appreciate this opportunity. You could, of course, be saddened by the fact that the original environment has disappeared. When you move a cultural heritage to a museum, you move it 
outside. However, this shifting is also a creative act." (Brown 2019)

Given the high-profile nature of the Rodin exhibition and its presence on the Internet seen worldwide, the question of the "Elgin Marbles" was reignited. From its opening on 26 April to its closing on 29 July 2018, there was a flurry of news articles and opinions posted using the British Museum's Twitter hashtag, \#RodinExhibition.

A news story in Artsy reported that the marbles "would be returned to their Mediterranean home under a Jeremy Corbyn premiership, the Labour leader told Greek paper Ta Nea" (Kaplin 2018). The ideas raised by Fischer draw on those often associated with the digital culture, interaction, context and new questions, and see the marbles 'in a context of world culture - claiming that "the monument's history is enriched by the fact that some [parts of it] are in Athens and some are in London where six million people see them every year" (Rea 2019). What will be the next move in this international debate. Already, some are suggesting that the answer lies in 3D printing - the question is, who gets what?

The British Museum's Rodin exhibition was followed by the British Petroleum (BP) sponsored exhibition, I am Ashurbanipal, king of the world, king of Assyria - "Warrior. Scholar - Empire builder - King slayer - Lion hunter - Librarian" (Brown 2018). BP's sponsorship drew outrage from the Iraqi community in London and across the diaspora which resulted in the staging of a mass protest by some 300 people while simultaneously the P21 London gallery mounted an exhibition under the title, I am British Petroleum: King of Exploitation, King of Injustice, that features Iraqi artists curated by "BP or not BP" an activist group and member of the Art Not Oil coalition. In this case, the protest of $I$ am Ashurbanipal took the form of an art exhibition bringing together the public, a gallery, an activist group and the artists on exhibit (ArtForum 2019; Harris 2019).

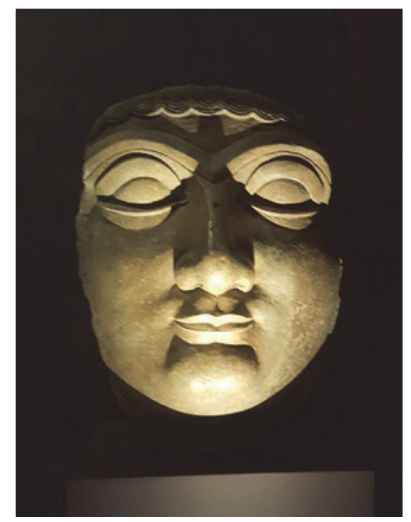

Figure 5: Face from a colossal sphinx carved in stone. South-West Palace. Nineveh, Iraq, about 700-695 BC. British Museum. Photograph by T. Giannini.

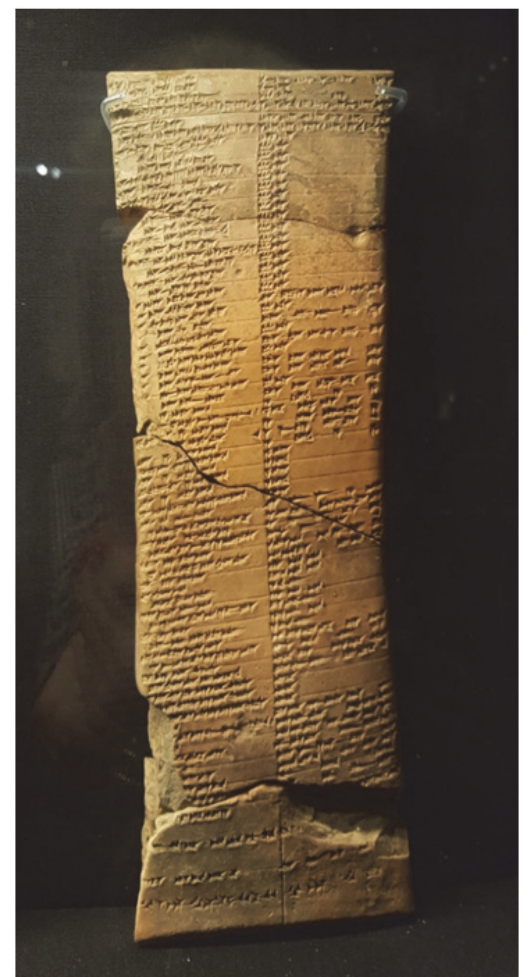

Figure 6: Table from the Royal Library of King Ashurbanipal, who ruled 669-631 BC. The Royal Library contained some 10,000 clay-tablet works and "united all written knowledge from Mesopotamia under one roof. It contained complete sets of classic reference works in professionally produced editions." From exhibitions wall plaque. Nineveh, 680-630 BC. British Museum. Photograph by T. Giannini.

\section{Performance Art and Protest}

The 1960s ushered in an era of activist artists protesting for civil rights and democracy. Bob Dylan's 1962 song, Blowin' in The Wind, became woven into the fabric of the civil rights protest movement.

\section{Yes, 'n' how many times can a man turn his head And pretend that he just doesn't see? \\ The answer, my friend, is blowin' in the wind \\ The answer is blowin' in the wind}

The notion of "blowin' in the wind" makes good connections with politics in our time that permeate the conversation across the digital ecosystem, yet not seen by museums until artists protest.

Looming large on the protest scene in the US during the 1960s and 1970s was the Vietnam War. A 2018 exhibition at the Whitney Museum, An Incomplete History of Protest, captures the Vietnam conflict through the art and ephemera produced around the cause of ending the war, showing the people, places and their messages (Whitney 2017). Like Internet memes today, they combined image and text in compelling and graphically innovative ways; they were lacerating in their critique and often brimmed with satire and gallows humour. 


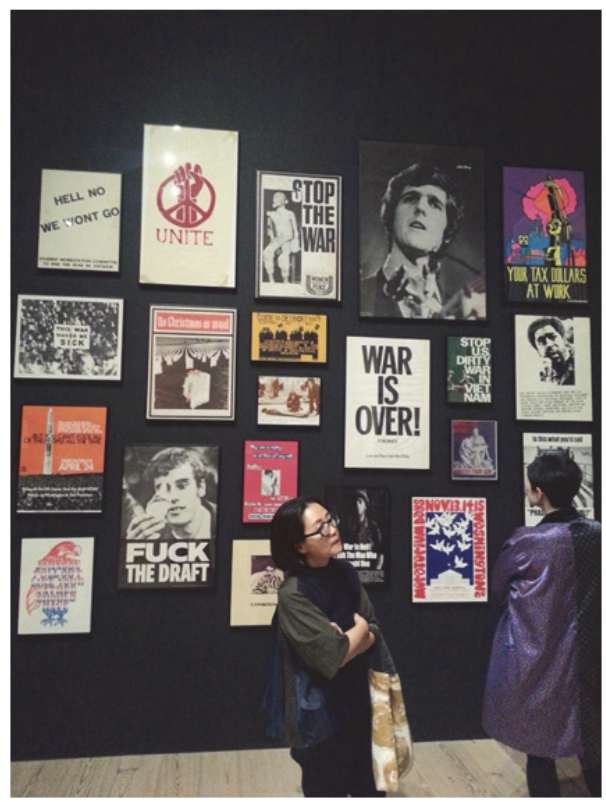

Figure 7: Installation view from the Whitney Museum exhibition, An Incomplete History of Protest, Selections from the Whitney's Collection, 1940-2017. Photograph by T. Giannini (August 2018).

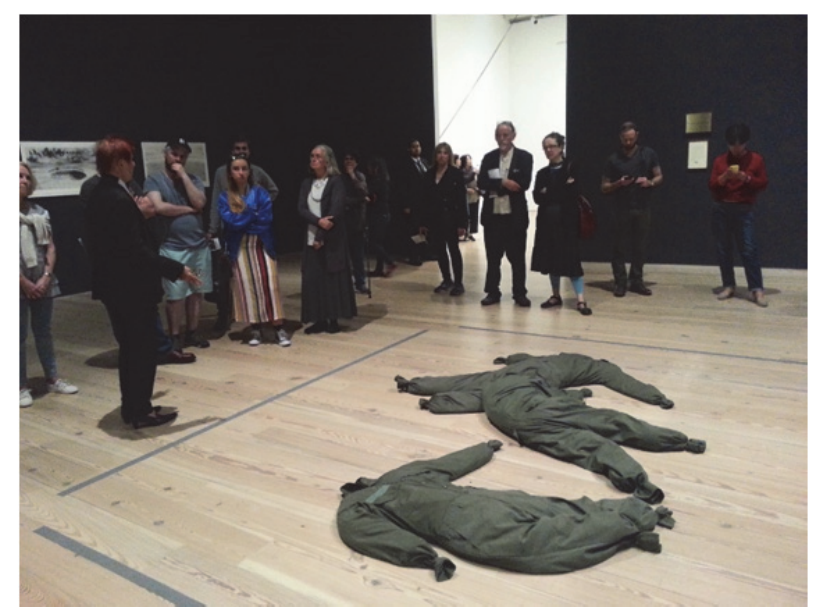

Figure 8: Installation view, from the Whitney Museum exhibition, An Incomplete History of Protest, showing The Non War Memorial (1970) by Edward Kienholz. "In addition to calling for direct political action, artists made singular works that addressed the war in Vietnam" as in this work which "simulates the carnage with sand-stuffed military uniforms scattered on the floor as if they are corpses." Photograph by T. Giannini (August 2018).

\section{Performance Art and Activism}

Performance art and artists are staging actions in museums that go viral receiving global attention over the Internet and high stakes publications as the NY Times. Corporations have unwittingly been dragged into the battleground of museum protest as donors of major exhibitions, most notably, the Sackler brothers, of Purdue Pharma, leading producer of the opioid Oxycontin, and British Petroleum for their support of British Museum exhibitions in the name Greenpeace and environmental groups.
Social justice groups across a broad range of issues particularly women's rights and the crisis of the abuse of women, LGBT, equal rights, racism, marginalized and underrepresented groups to cultural appropriation and rights to restitution, repatriation and control of the narrative.

\section{Nan Goldin, Photographer, Artist, and Activist}

Nan Goldin's photography found its home in the 1980s New York art scene when it coalesced around the LGBT movement, human sexuality and the AIDS crisis. Her ground-breaking 1985 work, The Ballad of Sexual Dependency, foretold her rise as an artist of influence and consequence, and a photographer in love with love. Now, thirty years since the publication of her artist's book of that title, Goldin is using her brush with death from Oxycontin as the basis of her performance art protest events in museums with Sackler galleries.

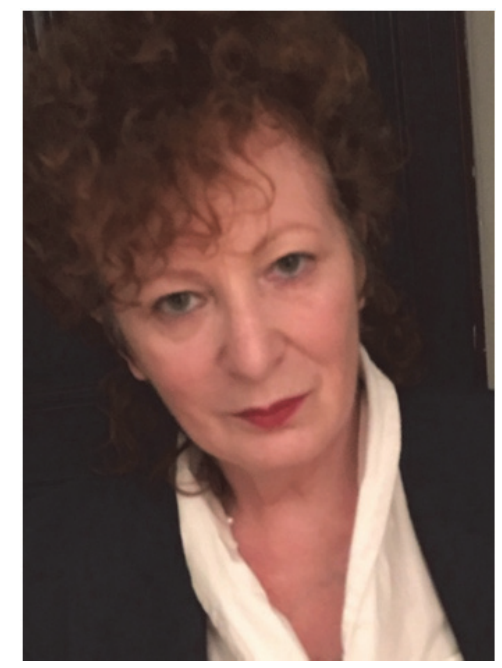

Figure 9: Portrait of Nan Goldin, June 2017. Photograph by Hazzzzzzi. Wikimedia Commons.

http://commons.wikimedia.org/wiki/File:Nan Goldin Portrait.png

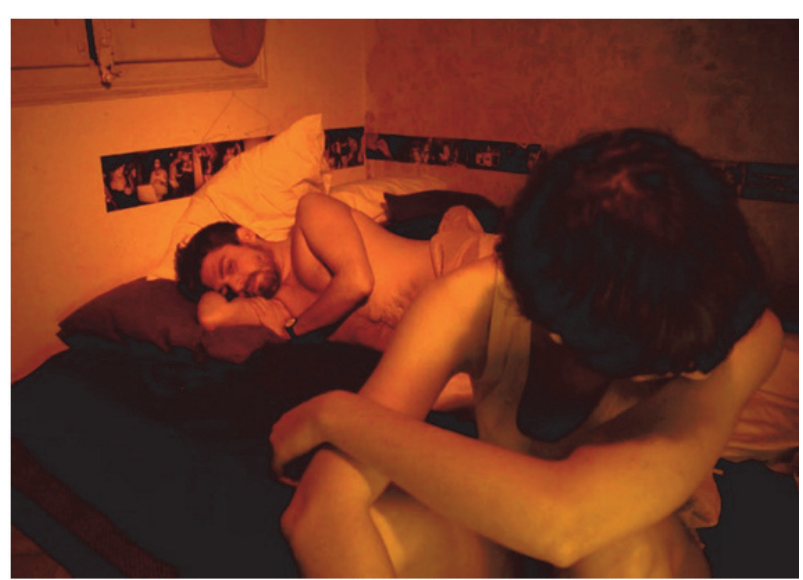

Figure 10: After Nan, photograph by Miquel Figueroa, Barcelona Spain. Many artist photographers find inspiration in Nan Goldin's work. Wikimedia Commons (April 2008). http://commons.wikimedia.org/wiki/File:After Nan..jpg 
It was the drug prescribed to Goldin as a pain killer for surgery, and which led her to OxyContin addiction, which has killed thousands, that caused her resolve to meet the opioid crisis head-on. Joined by many of fellow artists rallying around her cause célèbre, she formed the group P.A.I.N. (Prescription Addiction Intervention Now http://sacklerpain.org) and moved from photographer to performance artist and activist. Her stage, museums with Sackler galleries, and in particular the Met and Guggenheim, where her group has staged powerful anti-Sackler performance protests. At the Guggenheim, OxyContin paper prescriptions and pill containers rained down on to the floor of the Guggenheim, where Goldin and her followers held a "dye-in." Chanting protesters with posters and banners conveyed the message (Goldstein 2019).

\section{From the Legacy of Looted Art to Contemporary Museum Galleries}

In July 1937 in Munich, an exhibition entitled "degenerative art" bowed to Hitler's disdain of contemporary art and was a moment when the paths of Hitler and Churchill, who reacted as both artist and politician, crossed in a war of words. While Nazi authorities were confiscating thousands of art works by prominent artists of the German avant-garde, Churchill speaking at the Sea Power show, took the opportunity to condemn Hitler's actions against artists and his anti-Semitic rhetoric, saying that these, "were very drastic and formidable pronouncements" and that being an artist in Germany was "a very hazardous employment." He sarcastically quipped that, if "you had only the alternatives of being hung if your picture were accepted or hanged if it were rejected, it might put a great damper on individual enthusiasm."

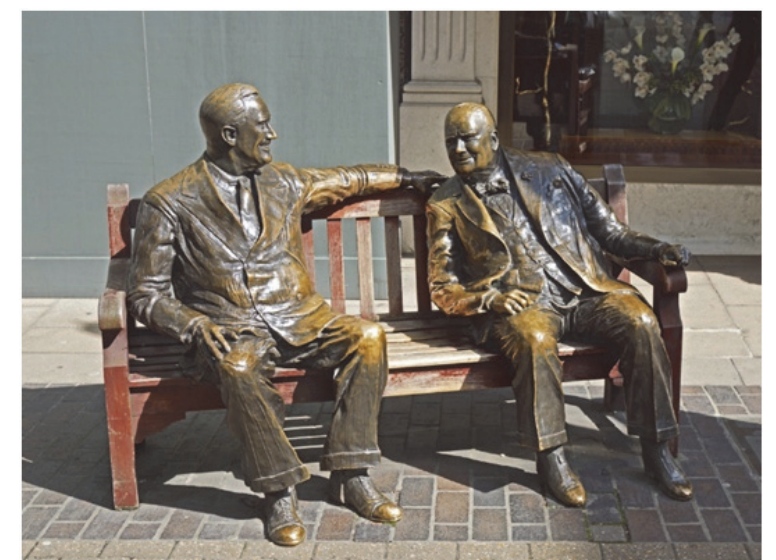

Figure 11: Special Relationship. Franklin D. Roosevelt and Winston Churchill, New Bond Street, London.

Sculpted by Lawrence Holofcener, American and British Sculpture, 1926-2017. Photograph by Anthony O'Neil. Wikimedia Commons.

http://commons.wikimedia.org/wiki/File:Special Relations hip\%3F (geograph 4125450).jpg
During the same summer, Nazi authorities confiscated some 17,000 works of modernist art from German museums, which had previously been at the forefront in collecting and exhibiting the avant-garde. In his brief remarks at the opening of the Sea Power show, Churchill gave his retort, which anticipated the speech he would make at the Royal Academy in the following year. David Cannadine (2019) in his book on Churchill, brings deep insight into Churchill's love of artistic expression and the relationship of art and politics:

\begin{abstract}
...by the late 1930 s he had come to recognize that freedom of artistic expression was essential to any society that cherished liberty, and that Hitler's attacks on art were one further indication of the evils of Nazi tyranny. Ever since he had been a wayward schoolboy, Churchill had fought for individualism against regimentation. Without freedom to paint, he now believed, there could be no freedom to live. Democracies valued artists; dictatorships did not. (Cannadine 2019)
\end{abstract}

Further, Cannadine notes:

A few days before, [July 1937], an exhibition entitled Entartete Kunst (Degenerate Art) had opened in Munich, the aim of which was to hold up modern art to public ridicule, and at which Hitler had spoken, denouncing all such work as "Jewish" or "Bolshevik. (Cannadine 2019)

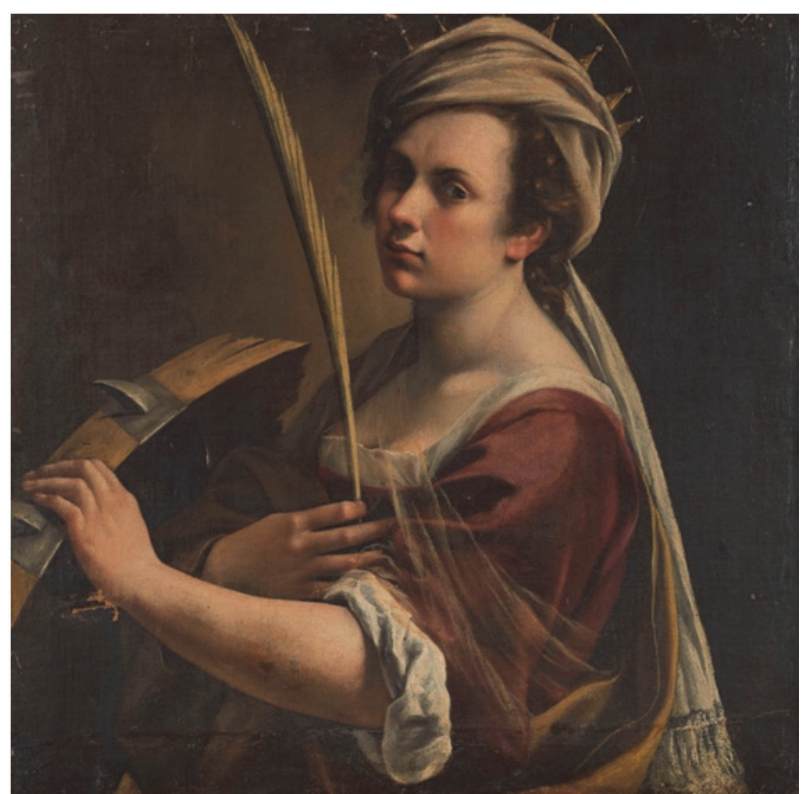

Figure 12: Self-Portrait as Saint Catherine of Alexandria Artemisia Gentileschi, painted 1615-1617 during the artist's time in Florence she represents herself the Christian martyr, St Catherine of Alexandria, following on the heels of the brutal treatment she suffered during her trial for rape in 1612. National Gallery Collection, purchased in 2018 for £3. 6 million, amid international concerns about gaps in the painting's provenance during a period associated with Nazi looting. http://en.wikipedia.org/wiki/Self-

Portrait as Saint Catherine of Alexandria 
And the spectre of Nazi looted art continues to haunt the art world - the National Gallery's recent purchase of Gentileschi's self-portrait has been clouded by doubts raised by gaps in provenance that might suggest Nazi ties hover (Pes 2018), while the history of abuse of women associated with the artist are only now being widely recognized and taken seriously. Yet this painting seemed out of view until the National Gallery purchase which has brought her image into sharp focus stimulating discussion around feminist issues during the Renaissance while bringing these into the present. Her self-portrait, a strong statement on identity, as she dresses herself in the cloak of the martyr, St Catherine of Alexandria (Kinsella 2018).

\section{Artists Against Climate Change}

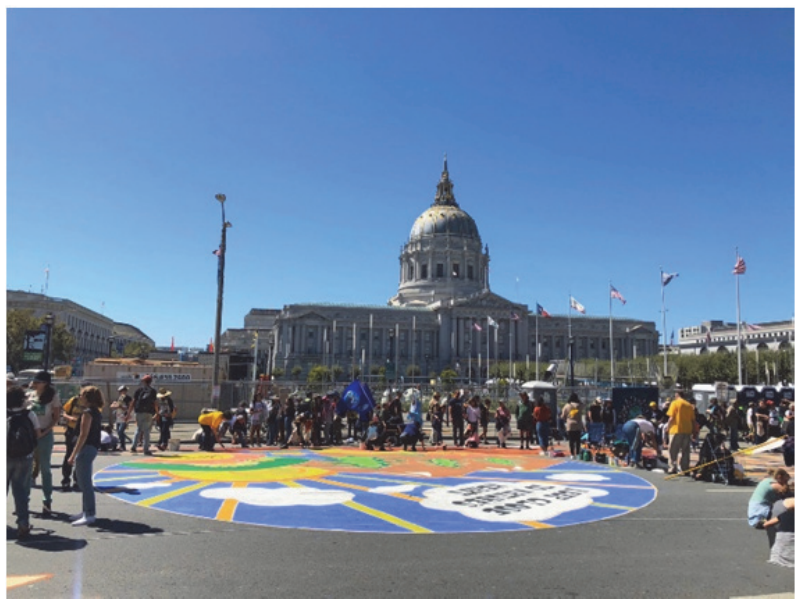

Figure 13: Art \& Activism for Climate Change.

Photograph by Fabrice Florin from Mill Valley, USA. Wikimedia Commons.

http://commons.wikimedia.org/wiki/File:Art and Activism for Climate Action (29725007537).jpg

In San Francisco, a quarter of a million people joined the Climate Action March around the world on September 8, 2018, asking for immediate action to reduce climate change. Thousands of artists and activists created one the largest street murals ever made, covering five blocks of city streets with dozens of colourful scenes illustrating possible solutions to global warming, all around the City Hall plaza (see Figure 12). The murals were designed by different community groups and painted on the ground in large 35-feet wide circles, using washable tempera paint. Murals were created by the Sierra Club ("Keep close to Nature's heart"), environmental students at University of California, Berkeley ("Fiat Lux") and San Francisco Unified School District ("Write History Wisely").

\section{Street Art - Public Messaging - Os Gêmeos and Triston Eaton}

For Tristan Eaton, "Outdoor, public art is the most important to me. Public art has the ability to inspire and transform our communities." And indeed, his hand spray-painted works in bold vivid colours convey an array of activist provocative messages. Street art has a long-held position as art and art form of political gesture while its ephemeral nature reflects the ever-changing city landscape where new building construction can lead to the demolition of works that have become part of a community city-scape, which is often met by strong protest. Despite the removal of many street art works, digital culture comes to the rescue, when works are documented digitally and can be seen online, for example on artists' websites.

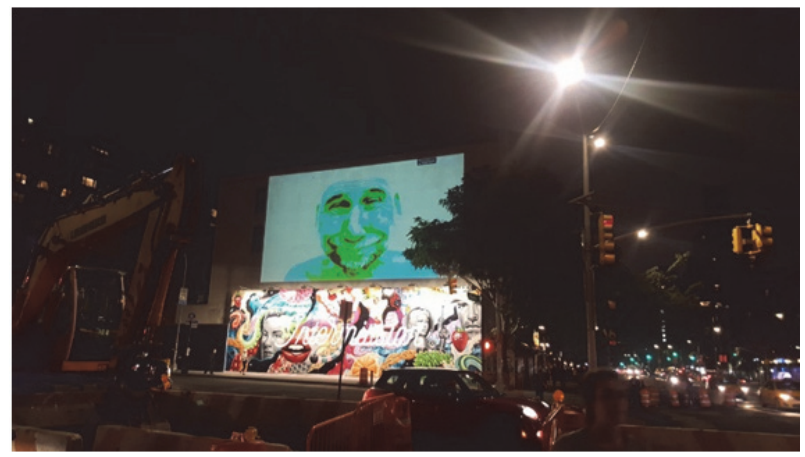

Figure 14: Intermission by Triston Eaton, Houston at Bowery Street, New York City. Photograph by T. Giannini (October 15, 2018). This stunning work, like a huge tapestry inspired by pop art images, occupies the

"Bowery mural wall." Above the mural is a digital Apple Store screen with changing images. At night, these works bring a burst of light and colour drawing many passers-by capturing the moment on their smartphone. The bulldozer to the left is tearing up the street and on the right is Bowery Street, with a bright streetlamp.

In August 2018, the first author was walking down $14^{\text {th }}$ Street from $7^{\text {th }}$ Avenue to the Pratt Institute building at $144 \mathrm{~W} .14^{\text {th }}$ St., her place of work, and was amazed to see that where a building had been demolished exposing two large red brick walls, there were two wonderful murals by Os Gemos, the acclaimed Brazilian graffiti artists and twin brothers.

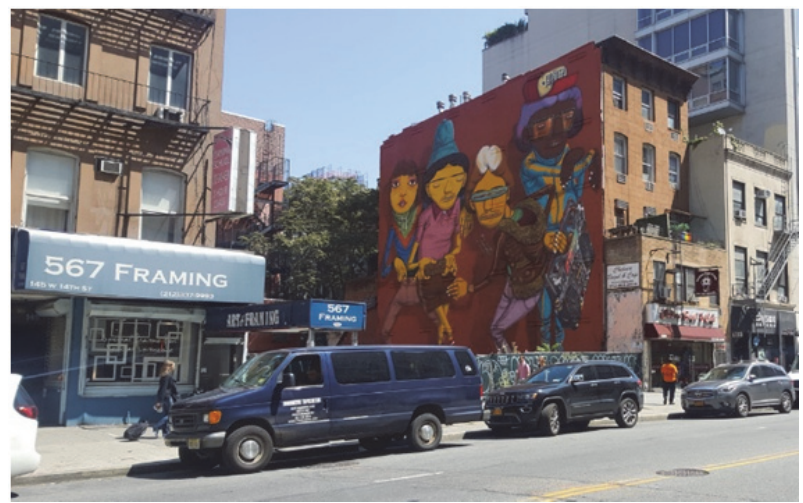

Figure 15: Mural by Os Gemos. Photograph by $T$. Giannini (August 23, 2018). This mural has already been preserved for digital culture and can be viewed on the artists' Facebook page showing 425,168 likes for the $14^{\text {th }}$ St. murals (http://www. facebook.com/osgemeos/). If and when a new building is erected between these walls, these works will be missed, but live on in cyberspace. 


\section{CONCLUSION}

Coming back to the words of Bob Dylan, 'Yes, ' $n$ ' how many times can a man turn his head - And pretend that he just doesn't see?" Nan Goldin takes up on the idea of seeing relating it to her early family life:

\begin{abstract}
I mean, I think I wanted to make a record of the world that I saw, the real world and not the pretty version of the real world; not a conservative version. I grew up in suburban Maryland and it was all about 'Don't let the neighbours know.' I saw all the pretence and all of the revisionism of everything. So I needed to make a record that couldn't be revised. And it can't really, whether people want to see it or want - (Hell, 2018)
\end{abstract}

The digital world makes seeing and knowing so freely accessible that we can see beyond our place, and across cyberspace to outer space in ways that touch our inner space and consciousness. Living now in the world of the loT and being connected 24/7, the linking of art and activism, in a world where artists deliver messages about self, the environment and the future, their work has taken on new powers of communication as their messages are "blowin' in the wind" floating in the digital cloud we share, and creating images of who we are, and with a click, we can see who we were, where we've come from, and we see that we have "promises to keep and miles to go before" we "sleep" (Frost 1923).

As we fast-forward into the world of artificial intelligence (AI), artists are finding new ways of seeing the world as they imagine new opportunities and challenges in the future.(Cascone 2018; Rea 2018) The Metropolitan's new partnership with MIT and Microsoft is using $\mathrm{Al}$ and machine learning to bring new ways of searching images (Kenny 2019) that brings new ways of seeing art and exploring collections (Schneider 2019). The VR artist Sougwen Chung reflects:

\begin{abstract}
"As an artist working with these tools, the promise of Al offers a new way of seeing," Chung explains. "Seeing as self-reflection, seeing through the ground truth of ones [sic] own artworks as data. There is a lot of talk about biases evident in $\mathrm{Al}$ systems and that is absolutely true within Al systems trained on art. You could describe visual language as a kind of visual bias, a foregrounding of the subjective view of the artist. By translating that into machine behaviour, I am attempting to create a shared intersubjectivity between human and machine." (Rea 2018)
\end{abstract}

If humans and machines can achieve a "shared intersubjectivity", will this impact human to human relationships? It seems, it has already changed the way we see ourselves, the world and our ways of being.

\section{Acknowledgements}

This paper has taken inspiration from a recent book (Giannini \& Bowen 2019) and previous EVA London papers (Bowen et al. 2017; 2018; Giannini \& Bowen 2016; 2017; 2018). Jonathan Bowen is grateful to Museophile Limited for financial support.

\section{REFERENCES}

Akbild (2019) PhD in Practice. Academy of Fine Arts Vienna, Austria.

https://www.akbild.ac.at/Portal/studium/studienrichtungen /phd-in-practice

ArtForum (2019) Hundreds Protest BP Sponsorship of British Museum. ArtForum News, February 18, 2019. https://www.artforum.com/news/hundreds-protest-bpsponsorship-of-british-museum-78655

Bowen, J. P., Diprose, G., and Lambert, N. (eds.) (2017) EVA London 2017: Electronic Visualisation and the Arts. BCS, Electronic Workshops in Computing (eWiC). http://www.bcs.org/ewic/eva2017

Bowen, J. P. and Giannini, T. (2014) Digitalism: The new realism? In K. Ng, J. P. Bowen, and S. McDaid (eds.), EVA London 2014: Electronic Visualisation and the Arts. BCS, eWiC, pp. 324-331. DOI: 10.14236/ewic/eva2014.38

Bowen, J. P., Giannini, T., and Polmeer, G. (2017) Coded Communication: Digital senses and aesthetics, merging art and life. In Bowen et al. (2017), pp. 1-8. DOI: $10.14236 /$ ewic/EVA2017.1

Bowen, J. P., Giannini, T., Polmeer, G., Gannis, C., Gardiner, J., Kearney, J., Wands, B., and Weinel, J. (2018) States of Begin: Art and identity in digital space and time. In Bowen et al. (2018), pp. 1-7. DOI: 10.14236/ewic/EVA2018.1

Bowen, J. P., Weinel, J., Diprose, G., and Lambert, N. (eds.) (2018) EVA London 2018: Electronic Visualisation and the Arts. BCS, Electronic Workshops in Computing (eWiC). http://www.bcs.org/ewic/eva2018

Brown, M. (2018) British Museum shines light on Assyrian 'king of the world'. The Guardian, UK, June 19, 2018.

https://www.theguardian.com/culture/2018/jun/19/britishmuseum-shines-light-on-assyrian-king-of-the-worldashurbanipal

Brown, M. (2019) British Museum chief: Taking the Parthenon marbles was 'creative'. The Guardian, UK, January 28, 2019.

https://www.theguardian.com/artanddesign/2019/jan/28/b ritish-museum-chief-taking-the-parthenon-marbles-wascreative

Cannadine, D. (2019) 'Audacity Is the Only Ticket': How Winston Churchill, an Amateur Artist, Treated Painting as a Battlefield. Artnet News, February 18, 2019 https://news.artnet.com/art-world/how-amateur-artistwinston-churchill-amateur-saw-painting-1456174 
Cascone, S. (2018). MIT Researchers Are Using Artificial Intelligence to Make Some of the Most Convincing Reproductions of Art Ever. Artnet News, December 5, $2018 . \quad$ https://news.artnet.com/art-world/artificialintelligence-is-reproducing-art-masterpieces-1405558

Fottrell, Q. (2018) People spend most of their waking hours staring at screens. MarketWatch, August 4, 2018. https://www.marketwatch.com/story/people-arespending-most-of-their-waking-hours-staring-at-screens2018-08-01

Frost, R. (1923) Stopping by Woods on a Snowy Evening.

https://en.wikipedia.org/wiki/Stopping by Woods on a Snowy Evening

Giannini, T. and Bowen, J. P. (2016) Curating Digital Life and Culture: Art and information. In J. P. Bowen, G. Diprose, and N. Lambert (eds.), EVA London 2016: Electronic Visualisation and the Arts. BCS, eWiC, pp. 237-244. DOI: 10.14236/ewic/EVA2016.46

Giannini, T. and Bowen, J. P. (2017) Life in Code and Digits: When Shannon met Turing. In Bowen et al. (2017), pp. 51-58. DOI: 10.14236/ewic/EVA2017.9

Giannini, T. and Bowen, J. P. (2018) Of Museums and Digital Culture: A landscape view. In Bowen et al. (2018), pp. 172-179. DOI: 10.14236/ewic/EVA2018.34

Giannini, T. and Bowen, J. P. (eds.) (2019) Museums and Digital Culture: New perspectives and research. Series on Cultural Computing. Springer.

Goldstein, C. (2019) 'It's Time, Guggenheim': Nan Goldin Launches a Surprise Demonstration at the Guggenheim Museum to Protest Its Sackler Funding. Artnet News, February 9, 2019.

https://news.artnet.com/opinion/metropolitan-museumartificial-intelligence-1461730

Harris, G. (2019) Exploitation and injustice': London gallery show protests BP sponsorship at British Museum. The Art Newspaper, February 1, 2019.

https://www.theartnewspaper.com/news/bp-p21

Hell, R. (2018) Downtown Legend Richard Hell Interviews Nan Goldin About Art, Opioids, and the Sadness of Life on the Fringes. Artnet News, November 8, 2018. https://news.artnet.com/art-world/nan-goldinrichard-hell-interview-1387933

Kaun, A. and Uldam, J. (2017) Digital activism: After the hype. New Media \& Society, September 19, 2017. DOI: $\underline{10.1177 / 1461444817731924}$
Kaplin, I. (2018) Labour leader Jeremy Corbyn would return the Elgin Marbles to Greece if elected Prime Minister. Artsy, June 4, 2018.

https://www.artsy.net/news/artsy-editorial-labour-leaderjeremy-corbyn-return-elgin-marbles-greece-electedprime-minister

Kenny, N. (2019) Met unveils its Al experiment with Microsoft and MIT - Teams produce five digital prototypes for acquainting people with images of museum objects online. The Art Newspaper, February 5 , 2019. https://www.theartnewspaper.com/news/metunveils-its-ai-experiment-with-microsoft-and-mit

Kinsella, E. (2018) London's National Gallery (Finally) Buys a Painting by Artemisia Gentileschi, Pioneering Female Artist of the Italian Renaissance. Artnet, July 6, 2018. https://news.artnet.com/market/national-portraitgallery-shells-record-4-million-artemesia-gentileschi-selfportrait-1314446

Pes, J. (2018) The National Gallery's New Artemisia Gentileschi Should Be a Triumph-But Clouds Are Forming Over Its Ownership During WWII. Artnet News, December 12, 2018.

https://news.artnet.com/exhibitions/national-galleryartemisia-gentileschi-provenance-1417675

Rea, N. (2018) Has Artificial Intelligence Brought Us the Next Great Art Movement? Here Are 9 Pioneering Artists Who Are Exploring Al's Creative Potential. Artnet News, November 6, 2018. https://news.artnet.com/market/9artists-artificial-intelligence-1384207

Rea, N. (2019) The British Museum Says It Will Never Return the Elgin Marbles, Defending Their Removal as a 'Creative Act'. Artnet News, January 28, 2019.

https://news.artnet.com/art-world/british-museum-wontreturn-elgin-marbles-1449919

Schneider, T. (2019) The Gray Market: How the Met's Artificial Intelligence Initiative Masks the Technology's Larger Threats (and Other Insights). Artnet News, February 11, 2019.

https://news.artnet.com/opinion/metropolitan-museumartificial-intelligence-1461730

Whitney (2017) An Incomplete History of Protest: Selections from the Whitney's collection, 1940-2017. Whitney Museum, USA, August 18-27, 2017. https://whitney.org/Exhibitions/AnIncompleteHistoryOfPro test?section=4\#exhibition-artworks

Wolkoff, J. (2019) The Avant-Garde Art That Was Made for TV. Artsy, January 23, 2019. https://www.artsy.net/article/artsy-editorial-avant-gardeart-made-tv 